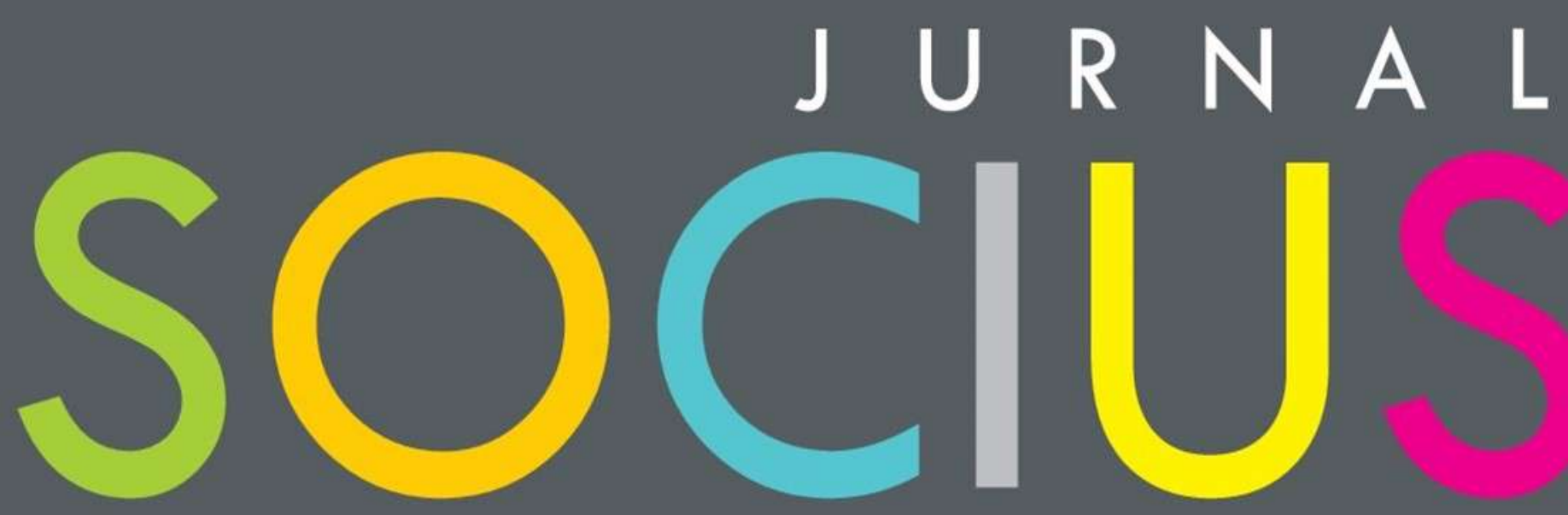

Journal of Sociology Research and Education

DITERBITKAN OLEH :

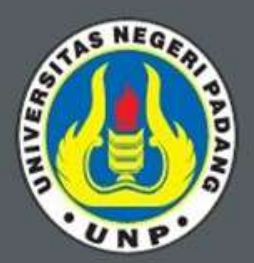

LABOR

JURUSAN SOSIOLOGI

FAKULTAS ILMU SOSIAL

UNIVERSITAS NEGERI PADANG

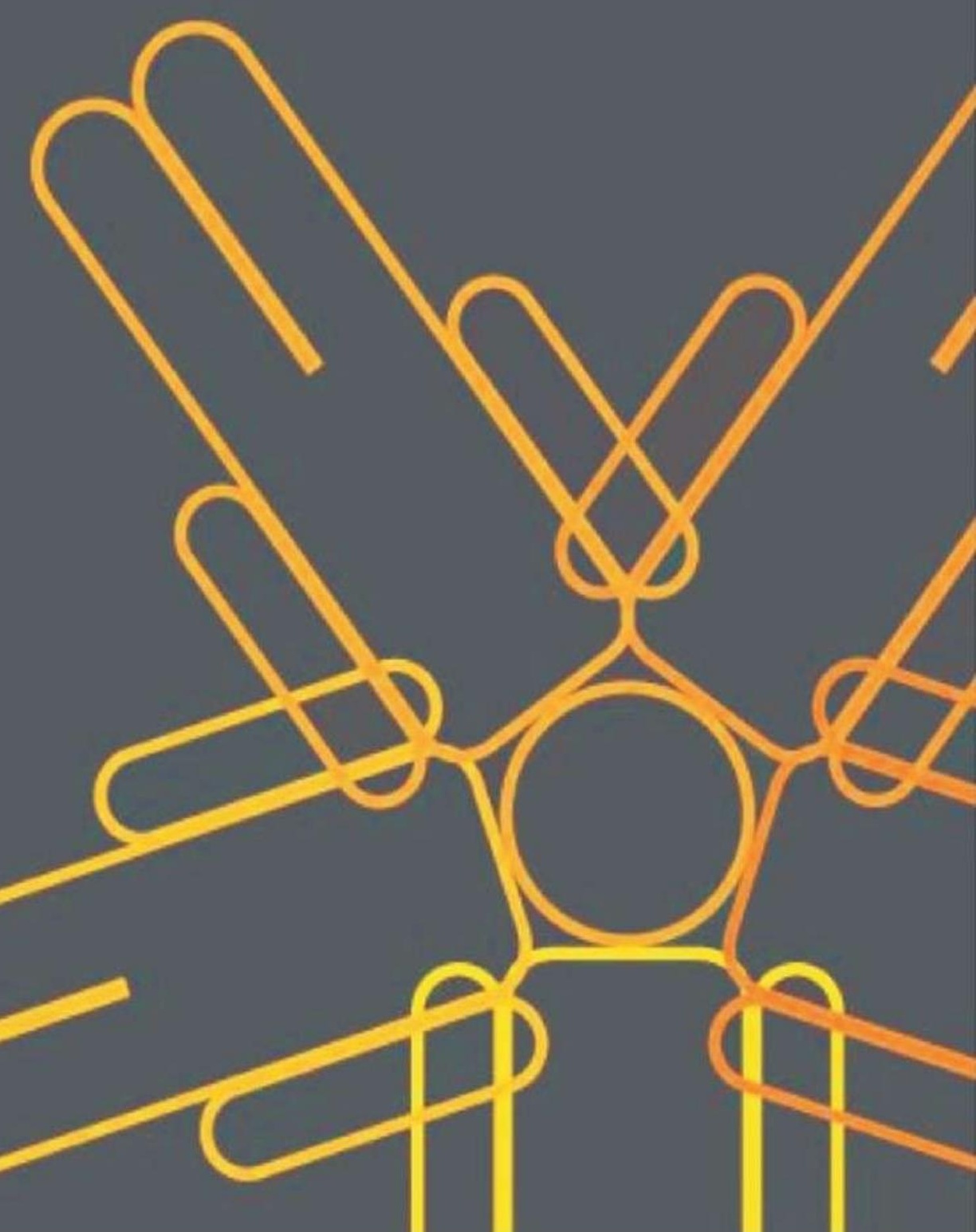




\section{SOCIUS}

Vol. 8, No. 1, Th. 2021

ISSN : 2356-4180 (cetak)

2442-8663 (online)

\begin{tabular}{|c|c|}
\hline $\begin{array}{c}\text { REDAKSI } \\
\text { JURNAL SOCIUS }\end{array}$ & DAFTAR ISI \\
\hline $\begin{array}{l}\text { Editor in Chief : } \\
\text { Desy Mardhiah } \\
\text { (Universitas Negeri Padang) }\end{array}$ & $\begin{array}{c}\text { Arni Darmayanti, Gede Budarsa } \\
\text { Peran Ganda Perempuan Bali di Masa Pandemi Covid-19 } \\
\text { Halaman } 1-12\end{array}$ \\
\hline $\begin{array}{l}\text { Managing Editor : } \\
\text { Erda Fitriani } \\
\text { (Universitas Negeri Padang) }\end{array}$ & $\begin{array}{c}\text { Luthfi Hasanal Bolqiah, Riaty Raffiuddin } \\
\text { Dominasi Oligarki dalam Pembangunan Reklamasi Pantai Utara Jakarta } \\
\text { Halaman 13-25 }\end{array}$ \\
\hline $\begin{array}{c}\text { Editorial Board: } \\
\text { Elfitra Baikoeni } \\
\text { (Universitas Andalas) }\end{array}$ & $\begin{array}{c}\text { Rinel Fitlayeni, Ikhsan Muharma Putra, Marleni Marleni, } \\
\text { Elvawati Elvawati, Winda Sri Yulia Putri }\end{array}$ \\
\hline $\begin{array}{c}\text { Iskandar } \\
\text { (Universitas Trunojoyo) }\end{array}$ & $\begin{array}{c}\text { Penguatan Kapasitas Pedagang dalam Resolusi Konflik Asimetris di } \\
\text { Pasar Raya Padang Pasca Gempa }\end{array}$ \\
\hline $\begin{array}{c}\text { Ike Sylvia } \\
\text { (Universitas Negeri Padang) }\end{array}$ & Halaman $26-35$ \\
\hline $\begin{array}{c}\text { Erianjoni } \\
\text { (Universitas Negeri Padang) } \\
\text { Emizal Amri } \\
\text { (Universitas Negeri Padang) }\end{array}$ & $\begin{array}{c}\text { Dahlia Morina Hutagalung, Ferdinand Kerebungu, Maryam } \\
\text { Lamadirisi } \\
\text { Perilaku Belajar Mahasiswa Batak Toba di Universitas Negeri Manado } \\
\text { Halaman 36-46 }\end{array}$ \\
\hline $\begin{array}{l}\text { Mohammad Isa Gautama } \\
\text { (Universitas Negeri Padang) }\end{array}$ & $\begin{array}{c}\text { Rifqi Asy'ari, Rusdin Tahir, Cecep Ucu Rakhman, Rifki } \\
\text { Rahmanda Putra }\end{array}$ \\
\hline $\begin{array}{l}\text { Khairul Fahmi } \\
\text { (Universitas Negeri Padang) }\end{array}$ & $\begin{array}{l}\text { Pengembangan Pariwisata Berbasis Masyarakat di Provinsi Jawa Barat } \\
\text { Halaman 47-58 }\end{array}$ \\
\hline $\begin{array}{c}\text { Reno Fernandes } \\
\text { (Universitas Negeri Padang) }\end{array}$ & $\begin{array}{c}\text { Reno Fernandes, Azwar Ananda, Maria Montessori, Firman } \\
\text { Firman, Eka Vidya Putra, Hendra Naldi, Erda Fitriani }\end{array}$ \\
\hline $\begin{array}{l}\text { Layout Editor : } \\
\text { Rhavy Ferdyan } \\
\text { Technical Support: } \\
\text { Rudi Mahesa }\end{array}$ & $\begin{array}{c}\text { Adaptasi Dosen Digital Immigrant Terhadap Pelaksanaan Pembelajaran } \\
\text { pada Masa Pandemi Covid-19 } \\
\text { Halaman 59-72 }\end{array}$ \\
\hline $\begin{array}{c}\text { Alamat Redaksi: } \\
\text { Jurusan Sosiologi FIS UNP } \\
\text { Jl. Prof.Dr.Hamka } \\
\text { Kampus UNP Air Tawar } \\
\text { e-mail: socius@ @ppj.unp.ac.id }\end{array}$ & \\
\hline $\begin{array}{c}\text { Penerbit } \\
\text { Labor Jurusan Sosiologi } \\
\text { Universitas Negeri Padang }\end{array}$ & \\
\hline
\end{tabular}




\title{
Penguatan Kapasitas Pedagang dalam Resolusi Konflik Asimetris di Pasar Raya Padang Pasca Gempa
}

\section{Rinel Fitlayeni ${ }^{1}$, Ikhsan Muharma Putra ${ }^{2}$, Marleni Marleni ${ }^{3}$, Elvawati Elvawati ${ }^{4}$, Winda Sri Yuli Putri ${ }^{5}$}

${ }^{1}$ Universitas Padjadjaran, ${ }^{1,2,3,4,5}$ STKIP PGRI Sumatera Barat

Email: rin31_inzaghi@yahoo.co.id

\begin{abstract}
Abstrak
Gempa bumi yang terjadi pada 30 September 2009 di Sumatera Barat, berdampak besar pada aktivitas ekonomi di Pasar Raya Padang, salah satunya pada aktivitas jual beli antara pedagang dan pembeli. Gempa bumi menyebabkan kerugian materil dan immateril bagi pedagang, yang menyebabkan mereka kehilangan sumber mata pencaharian utama. Kondisi ini membutuhkan penanganan khusus dari berbagai kelompok, salah satunya oleh Pemerintahan Kota Padang. Untuk mengatasi berbagai dampak yang merugikan pedagang, maka tindakan utama yang dilakukan Pemerintah Kota Padang adalah melakukan proses rehabilitasi dan rekonstruksi terhadap pasar raya. Namun tindakan ini memicu protes dari pihak pedagang, karena mereka merasa tidak dilibatkan dalam proses tersebut. Aksi protes ini berujung pada terjadinya konflik yang tidak seimbang (konflik asimetris), antara kelompok yang memiliki kekuasaan (power) dan pihak yang tidak berkuasa (powerless). Sebagai upaya untuk penyelesaian konflik tersebut, maka dilakukan pendekatan kepada pihak yang berkonflik untuk memperkuat kapasitas mereka sebagai bagian resolusi konflik. Tujuan penelitian ini adalah untuk menjelaskan penguatan kapasitas pedagang dalam resolusi konflik asimetris Pasar Raya Padang Pasca Gempa. Pendekatan yang digunakan dalam penelitian ini adalah pendekatan kualitatif dengan metode studi kasus. Adapun teknik pengumpulan data yang dilakukan melalui wawancara mendalam, studi dokumen dan FGD. Temuan penelitian menunjukkan bahwa resolusi konflik ditempuh melalui PBHI selaku kelompok pendamping dalam konflik asimetris tersebut, dengan melakukan penguatan pada kapasitas pedagang dengan cara; 1) penguatan pada sumber daya manusia, 2) penguatan organisasi.
\end{abstract}

Kata kunci: Gempa bumi, Konflik asimetris, Peningkatan kapasitas, Resolusi konflik

\begin{abstract}
The earthquake that occurred on September 30, 2009, in West Sumatra, had a major impact on economic activity at Pasar Raya Padang, one of which was buying and selling activities between traders and buyers. The earthquake caused material and immaterial losses to traders, which caused them to lose their main source of livelihood. This condition requires special handling from various groups, one of which is the Padang City Government. To overcome various adverse impacts on traders, the main action taken by the Padang City Government is to carry out a rehabilitation and reconstruction process for the market. However, this action sparked protests from the traders, because they felt they were not involved in the process. These protests led to an unequal conflict (asymmetrical conflict), between groups that have power (power) and those who are not in power (powerless). As an effort to resolve the conflict, an approach is taken to the conflicting parties to strengthen their capacity as part of conflict resolution. The purpose of this study is to explain strengthen the capacity of traders in asymmetric conflict resolution at Pasar Raya Padang after the Earthquake. The approach used in this research is a qualitative approach with a case study method. The data collection techniques were carried out through in-depth interviews, document studies, and FGDs. The research findings indicate that conflict resolution is pursued through PBHI as a companion group in the asymmetric conflict, by strengthening the capacity of traders using; 1) strengthening of human resources, 2) strengthening of the organization.
\end{abstract}

Keyword: Asymmetric conflict, Capacity building, Conflict resolution, Earthquake

Jurnal Socius: Journal of Sociology Research and Education Vol. 8, No. 1, Th. 2021 


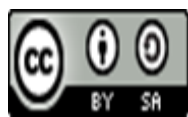

\section{Pendahuluan}

Gempa bumi yang terjadi di Sumatera Barat pada tahun 2009, mengakibatkan banyak kerugian dan kerusakan, baik secara materil maupun immateril. Salah satu kerusakan yang parah terjadi pada bangunan Pasar Raya Kota Padang Padang. Banyak bangunan yang rusak berat, sehingga mengganggu aktifitas ekonomi yang terjadi antara pembeli dan penjual. Kondisi ini menarik perhatian khusus dari berbagai pihak terutama Pemerintah Kota Padang. Hal ini karena pasar merupakan lembaga ekonomi yang menggerakkan dinamika kehidupan ekonomi masyarakat (Damsar, 2002). Berbagai tindakan telah dilakukan oleh Pemerintah Kota Padang, untuk memulihkan kembali kondisi Pasar Raya Padang pasca gempa, diantaranya proses revitalisasi, rehabilitasi dan rekonstruksi. Proses pertama yang dilakukan adalah proses revitalisasi terhadap bangunan yang hancur. Bangunan yang hancur diperbaiki agar bisa dimanfaatkan kembali oleh pedagang. Proses ini dilakukan berdasarkan undang-undang yang berlaku yakni UU No. 24 Tahun 2007 terkait penanggulangan bencana, selain itu Peraturan Pemerintah Nomor 21 tahun 2008, serta peraturan perundang lainnya. Selain itu revitalisasi yang dilakukan juga memperhatikan kebutuhan para pedagang melalui proses perencanaan yang matang.

Proses selanjutnya yang juga diperhatikan adalah proses rehabilitasi dan rekonstruksi, yang disesuaikan dengan perjanjian antara pedagang dengan pemerintah Kota Padang. Proses rehabilitasi dan rekonstruksi tersebut juga tidak bisa dilepaskan dari hak pedagang sebagai korban gempa. Artinya agar proses tersebut sesuai dengan undang-undang yang berlaku maka pemerintah harus melibatkan pedagang dalam rehabilitasi dan rekontruksi. Awal proses rehabilitasi dan rekontruksi yang dilakukan oleh pemerintah sudah menuai kecaman dan terjadi pelanggaran karena terjadi pemagaran paksa gedung pasar inpres II, III dan IV dengan melibatkan aparat yakni Polri, TNI dan Satpol PP. Kondisi ini berujung jatuhnya korban dari pihak pedagang, yang tentu tidak bisa dibenarkan karena melanggar hak azazi manusia. Selain itu pemagaran paksa tersebut juga dilakukan dengan bertepatan pada 1 Syawal $1432 \mathrm{H}$, dimana umat muslim sedang menjalani hari raya Idul Fitri. Padahal sebelum terjadi pemagaran paksa, pemerintah sudah berjanji akan melakukan rehabilitasi dan rekontruksi Pasar Raya Padang melalui musyawarah dengan pedagang terutama korban gempa. Kenyataannya komitmen tersebut dilanggar oleh Pemerintah Kota Padang.

Ambruknya bangunan Pasar Raya Padang, membuat pemerintah Kota Padang harus pro aktif untuk mencarikan tempat relokasi untuk pedagang sebagai alternatif solusi agar mereka tetap bisa berdagang. Adapun solusi yang diberikan dengan membangun tenda darurat untuk berdagang. Namun, akibat pembangunan tenda darurat tersebut, toko yang tidak terkena dampak gempa tertutupi oleh lapak-lapak yang dibangun, sehingga mereka menolak pembangunan tenda darurat tersebut. Penolakan yang dilakukan oleh pedagang disebabkan karena sejak dibangun tenda darurat, pendapatan pedagang menurun, karena sepi pengunjung. Selain itu akses pembeli pun tidak ada ke pedagang karena jalur angkot (angkutan kota) yang ditutup oleh pemerintah Kota Padang berkenaan jalur di gunakan untuk pasar darurat.

Penolakan pedagang ini kemudian ditunjukkan dalam bentuk demonstrasi besar-besaran. Aksi demonstrasi ini bergabung dengan Forum Warga Kota (FWK) ke DPRD Kota Padang serta meminta wakil rakyat menerima aspirasi pedagang. Adapun aspirasi yang dituntut pedagang adalah pembongkaran pasar darurat yang sudah dibangun oleh pemerintah Kota Padang. Akan tetapi pemerintah tetap ingin mempertahankan kios darurat dengan alasan pembangunan tersebut telah mengeluarkan dana milyaran rupiah. Penolakan yang oleh 
pedagang terhadap pembangunan tenda darurat mempertajam konflik yang selama ini sudah terjadi karena muncul dari berbagai kepentingan dari kelompok (Pruitt \& Rubin, 2004).

Dalam menjalankan aksinya FWK mencari kuasa hukum yang bisa mendampingi dan melindungi aksi mereka. Proses perlindungan hukum diberikan kepada PBHI Sumatera Barat (Perlindungan Bantuan Hukum dan Hak Asasi Manusia Indonesia). PBHI merupakan organisasi nonprofit yang bekerja atas kepedulian sosial pada masyarakat yang terlibat pada persoalan hukum. PBHI selaku kuasa hukum melakukan beberapa cara dalam mendampingi pedagang melalui penguatan kapasitas kelompok, guna menyelesaikan konflik asimetris antara pedagang dan pemerintah Kota Padang. Tulisan bertujuan untuk membahas bentuk penguatan kapasitas pedagang dalam proses resolusi konflik asimetris pasca gempa di Pasar Raya Kota Padang.

Menurut Lewis A. Coser proses penyelesaian konflik dapat dilakukan melalui model katup penyelamat (safety valve) (Poloma, 1994). Coser beranggapan bahwa dalam setiap masyarakat seringkali berkembang suatu mekanisme untuk meredakan ketegangan yang ada, sehingga struktur sebagai keseluruhan tidak terancam keutuhannya. Menurut Coser, katup pengaman ini di samping dapat berbentuk institusi sosial dapat juga berbentuk tindakantindakan atau kebiasaan-kebiasaan yang dapat mengurangi ketegangan kerena konflik tidak dapat tersalurkan. Pengaturan konflik berupa bentuk-bentuk pengendalian atau pengelolaan konflik lebih diarahkan pada manifestasi konflik daripada sebab-sebabnya. Dengan asumsi bahwa konflik tidak mampu diselesaikan dan dibasmi, maka konflik dapat diatur sedemikian rupa sehingga konflik tidak menyebabkan perpecahan dalam masyarakat.

Dahrendorf menyebutkan tiga bentuk pengaturan atau pengelolaan konflik. Pertama, lewat mekanisme konsiliasi. Di ijalankan dengan dialog secara terbuka baik lewat lembaga parlemen atau quasi-parlemen tanpa ada yang mendominasi pembicaraan atau memaksakan kehendak. Kedua, lewat mekanisme mediasi, melalui pihak ketiga dalam menuntaskan konflik yang tengah dialami. Pihak ketiga ini bisa datang dari tokoh masyarakat, pakar atau ahli di bidangnya, atau lembaga tertentu. Ketiga, lewat mekanisme arbitrasi atau perwasitan. Masingmasing pihak yang tengah berkonflik sepakat untuk menyelesaikan urusannya untuk mendapatkan keputusan akhir secara legal. Arbitrator ialah lembaga-lembaga arbitrase atau pengadilan, sehingga keputusan yang dihasilkan bersifat legal. Dalam konteks konflik di Pasar Raya Padang pasca gempa 2009, arbitrator dalam hal ini dilakukan oleh PBHI selaku pihak pendamping yang memberikan perlindungan dan penyadaran. Selain itu juga melalui pihak ketiga yang dianggap sebagai pihak yang netral seperti DPRD. Sehingga melalui proses pendampingan ini, diharapkan kapasitas pedagang akan menguat, sehingga memperlancar proses resolusi konflik asimetris yang terjadi dengan pihak pemerintah.

Studi terkait dengan konflik pasar pernah dilakukan oleh Ariesta (2014) dengan judul Peran Perempuan Dalam Proses Resolusi Konflik (Studi Kasus Proses Resolusi Konflik Rehabilitasi dan Rekonstruksi Pasar Raya Padang). Hasil penelitian mendeskripsikan kesenjangan peran perempuan pada konteks sistem matrilineal budaya Minangkabau dalam proses resolusi konflik rehabilitasi dan rekonstruksi Pasar Raya Padang. Kesenjangan tersebut dalam arti perempuan diharapkan aktif berperan dalam setiap proses resolusi konflik, namun kenyataannya peran perempuan sangat kecil pada proses resolusi konflik ini. Tindakan kolektif yang dilakukan perempuan sebagai bentuk peran menuju proses resolusi konflik justru membawa perempuan sebagai korban kekerasan. Namun, ketika proses resolusi konflik secara formal dilakukan melalui perundingan, perempuan tidak lagi berperan dan mengikuti proses tersebut (Ariesta, 2014). Makna sistem budaya matrilineal yang disandingkan dengan struktur politik patriarki dalam budaya Minangkabau tentang keutamaan laki-laki sebagai perwakilan urusan publik dan pemimpin sebuah organisasi diterapkan oleh pihak yang terlibat sehingga menjadi penghambat peran perempuan dalam proses resolusi konflik ini.

Firdaus juga mengkaji lebih dalam terkait konflik Pasar Raya Kota Padang. Kajian ini

Jurnal Socius: Journal of Sociology Research and Education Vol. 8, No. 1, Th. 2021 
menfokuskan perhatian pada Protes Korban Bencana; Studi Konflik Penanggulangan Bencana di Pasar Raya Padang. Firdaus pada kajian ini menemukan bahwa ada beberapa peristiwa penting yang memunculkan aksi protes pedagang Pasar Raya Kota Padang kepada pemerintah Kota Padang terutama terkait kebijakan yang dikeluarkan oleh Pemko Padang. Kebijakan tersebut adalah; pembangunan kios darurat yang dianggap merugikan pedagang, Kebijakan pembangunan ulang pasar Inpres I, II, III dan IV yang dianggap pedagang tidak sesuai dengan kebutuhan pedagang dan keluar dari konteks penanggulangan bencana, serta pembangunan pertokoan fase VII lantai II dan III yang mengharuskan pengosongan pada lantai I. Adapun bentuk protes yang dilakukan pedagang adalah melalui APPR (Asosiasi Pedagang Pasar Raya) Padang, membentuk strategi bersama dengan FWK (Forum Warga Kota) dan strategi protes bersama PBHI Sumbar (Firdaus, 2014). Sejalan dengan itu Musrifah (2017) mengkaji tentang konflik dalam proses relokasi pedagang Pasar Ngabull Kecamatan Tahunan Kabupaten Jepara bahwa konflik yang terjadi disebabkan pemerintah setempat dan panitia relokasi memiliki kepentingan untuk mewujudkan ketertiban umum sedangkan pedagang disini lain ingin mendapatkan kepentingan. Kepentingan yang berbeda inilah yang menyebabkan pemicu terjadinya konflik.

Meskipun penelitian di atas, telah membahas tentang resolusi konflik pasca gempa, namun sebatas mengkaji tentang protes korban terhadap kebijakan pemerintah (Firdaus, 2014), dan ketidakadilan gender dalam proses resolusi konflik (Ariesta, 2014). Sementara penelitian ini fokus kepada peningkatan kapasitas kelompok pedagang dalam proses resolusi konflik. Oleh karena itu, penguatan-penguatan yang diberikan kepada pedagang dalam resolusi konflik asimetris pasca bencana adalah kebaruan dalam tulisan ini. Penelitian ini penting untuk dilakukan, karena dalam proses penyelesaian konflik kapasitas pedagang menjadi faktor penting yang menentukan keberhasilan proses tersebut.

\section{Metode Penelitian}

Pendekatan yang dilakukan untuk menganalisis permasalahan melalui pendekatan kualitatif dengan metode studi kasus. Teknik pengumpulan data melalui wawancara mendalam, dokumen terkait permasalahan serta proses observasi. Wawancara yang dilakukan adalah wawancara mendalam yaitu sebuah wawancara tidak terstruktur antara pewawancara dengan informan yang dilakukan berulang-ulang kali dengan pertanyaan yang berbeda dan mengklasifikasi informasi yang sudah dapat sebelumnya (Afrizal, 2008). Selain studi dokumen, proses pengumpulan data melalui wawancara dan observasi serta melalui Focus Group Discussion (FGD) yang dilaksanakan dua kali yang dilakukan dengan melibatkan pihakpihak yang terlibat konflik seperti pedagang dan PBHI. Observasi dilakukan di Pasar Raya Padang dengan mengamati sisa-sisa relokasi pasar dan mengamati bangunan dan fasilitas pasar yang sudah ada dan yang pernah dipertentangkan. Foto-foto juga digunakan untuk membahas persoalan pada saat wawancara mendalam dilakukan ke pihak-pihak yang terkait terutama dengan pedagang yang terlibat konflik secara langsung dan melakukan penolakan terhadap kebijakan rehabilitasi dan rekontruksi serta Dinas Pasar dan PBHI. Data juga didapatkan melalui kliping dan dokumen yang dimiliki oleh PBHI. Data yang di kumpulkan dianalisis dengan model analisis integratif Miles dan Huberman; 1992. Data berupa hasil wawancara, dokumen yang sudah di pelajari serta bukti bukti lapangan hasil observasi kemudian dianalisis dan direduksi hingga kemudian dapat disajikan berupa tulisan-tulisan (Miles, 1992). Proses reduksi menjadi point penting dilakukan untuk menarik kesimpulan dari hasil penelitian. 


\section{Hasil dan Pembahasan}

\section{Kronologis Konflik di Pasar Raya Padang Pasca Gempa}

Tidak bisa dipungkiri bahwa pasar raya merupakan salah satu urat nadi aktifitas ekonomi Kota Padang. Selain karena posisinya di pusat kota, pasar raya juga merupakan pasar induk dari pasar satelit yang ada di Kota Padang. Setelah gempa yang melanda Kota Padang pada 30 september 2009, kondisi pasar raya rusak berat dengan beberapa bangunan yang ambruk dan tidak dapat berfungsi lagi. Hal ini berdampak pada keberlangsungan kehidupan para pedagang, selain menyebabkan jatuhnya korban jiwa, kondisi ini juga berdampak pada kerugian materi karena tidak bisa lagi berjualan seperti biasa. Sebagai solusi permasalahan ini maka Pemerintah Kota Padang segera melakukan tindakan rehabilitasi dan rekontruksi. Namun dalam proses rehabilitasi dan rekonstruksi yang dilakukan oleh pedagang ternyata tidak melibatkan pihak pedagang. Kondisi inilah yang memicu terjadinya konflik berkepanjangan diantara dua kelompok tersebut. Menurut informan proses rehabilitasi dan rekontruksi hanya diberitahukan oleh kepada pedagang melalui pemberitahuan Walikota Padang Nomor 5111.2.72.1/Ps-2001 tertanggal 19 Januari 2011 terkait pemutusan layanan pasar di lokasi pasar inpres II, III dan I, seperti yang diungkapkan oleh Ibu ID, beriukut ini:

“...Pada dasarnya ibu setuju untuk dibangun kios darurat karena memang ini yang kita butuhkan karena tempat jualan kita sudah hancur akibat gempa, tetapi seharusnya pemerintah memberikan sosialisasi terlebih dahulu kepada kami mengenai pembangunan kios darurat itu (Wawancara pada Oktober 2019).

Surat Pemberitahuan Walikota Padang yang diberikan kepada pedagang tersebut, tujuannya agar pedagang segera mengosongkan pasar inpres II, III dan IV terkait akan segera dilakukan pembongkaran dan akan dibangun kembali bangunan pasar. Selain pengumuman yang hanya dilakukan melewati surat pemberitahuan, pedagang juga tidak pernah mendapatkan hasil verifikasi terkait kerusakan bangunan pasar untuk kelayakan bangunan. Di sisi lain pedagang sudah mendapatkan hasil pengujian dari Institut Teknologi Padang (ITP) yang menyatakan bahwa gedung tersebut masih layak huni. Faktor ini juga salah satu alasan penolakan terhadap pembongkaran yang dilakukan oleh pemerintah, seperti yang diungkapkan oleh Bapak IR, bahwa:

“...Kami menolak rencana pembongkaran yang dilakukan oleh pemerintah karena bangunan pasar masih layak dihuni, apalagi kelayakan tersebut berdasarkan pengujian yang dilakukan oleh Institut Teknologi Padang (ITP) yang menyatakan masih layak untuk ditempati dan tidak perlu melakukan pembongkaran (Wawancara pada Oktober 2019).

Kondisi ini menyebabkan pedagang melakukan berbagai sikap terkait penolakan mereka terhadap kebijakan yang dikeluarkan oleh pemerintah. Penolakan ini tertuang melalui sikap sejumlah organisasi pedagang seperti pedagang Petak Batu Bagonjong, Pasar Inpes II (KPB), Ikatan Pedagang Pasar II Lt 1 (IPPI), Forum Komunikasi Pedagang Pasar Raya Inpres III Lt 1 (FKP2-I) dan dewan pimpinan daerah Ikatan Pedagang Kecil (IPK) Kota Padang dengan menyampaikan bahwa pemerintah hanya melakukan perbaikan bangunan dan fasilitas pasar guna pemulihan kenyamanan dan kelancaran kegiatan para pedagang. Asumsi ini tidak terlepas dari bangunan yang dihuni oleh pedagang masih layak huni sesuai dengan surat Gapeksindo Peduli Sumbar Np. 55/Gapeksindo/2009 tertanggal 2 November 2009 yang menyatakan bahwa bangunan pasar inpres II, III dan IV masih layak dihuni oleh pedagang.

Proses rehabilitasi dan rekonstruksi pasca gempa yang dilakukan oleh pedagang melalui rencana pembongkaran dan pemabangunan kembali bangunan tersebut seharusnya dilakukan berdasarkan perundang-undang yang berlaku dalam penanggulangan bencana yakni PP No.21 tahun 2008 terkait penyelenggaraan penanggulangan bencana dan peraturan kepala BNPB No.

Jurnal Socius: Journal of Sociology Research and Education Vol. 8, No. 1, Th. 2021 
11 tahun 2008 mengenai pedoman pelaksanaan rekontruksi pasca bencana. Kenyataannya pelaksanaan yang dilakukan oleh pemerintah Kota Padang tidak menyertakan pemenuhan hakhak pedagang di pasar inpres II, III dan IV. Kondisi ini menguatkan alasan bahwa pemerintah tidak berlandaskan pada undang-undang kebencanaan.

Selain itu pengosongan dan pembangunan kembali pasar inpres II, III dan IV yang dilakukan oleh pemerintah dengan merelokasi pedagang untuk menempati kios penampungan juga ditentang oleh pedagang. Hal ini disebabkan bahwa kios penampungan tidak sesuai dengan jumlah pedagang. Menurut pedagang, kios di tempat penampungan sementara dengan jumlah pedagang yang direlokasi berbeda. Dimana jumlah kios penampungan berkisar 624 unit sedangkan pedagang terdiri 379 pedagang inpres II lt 1, 60 pedagang pasar bagonjong, 249 pedagang pasar inpres III lt 1 dan 2019 pedagang pasar inpres II lt 2.

Kondisi di atas berdampak pada semakin rumitnya aktivitas di Pasar Raya Padang. Pada awalnya pasar raya hanya sebagai tempat berlangsungnya aktifitas ekonomi semata, namun saat ini juga menjadi arena pertarungan berbagai kepentingan yang memunculkan gejolak sosial dan politik. Gejolak politik yang dimaksud tidak terlepas dari kebijakan yang dilakukan oleh pemerintah Kota Padang dalam proses rehabilitasi dan rekontruksi yang ditentang oleh pedagang. Bentuk penentangan yang dilakukan oleh pedagang melalui aksi protes demonstrasi. Inilah yang menjadi titik baru bagi berlangsungnya konflik yang berkepanjangan, antara pemerintah Kota Padang dengan pedagang, terutama terkait masalah rehabilitasi dan rekontruksi pembangunan pasar raya.

Demonstrasi yang dilakukan oleh pedagang, diawali pada hari Senin, 4 Januari 2010. Protes ini untuk menolak penempatan kios penampungan dengan bergabung dengan FWK (Forum Warga Kota) untuk melakukan unjuk rasa dengan jumlah sekitar 2000 orang ke kantor DPRD Kota padang. Aksi selanjutnya dengan menggelar tutup toko bersama FWK Kota Padang dilakukan pada tanggal 10 februari 2010. Aksi selanjutnya dilakukan pada hari kamis, untuk kembali menggelar aksi ke DPRD untuk menggelar sidang paripurna.

Konflik yang terjadi antara dua kelompok bukan saja dalam bentuk aksi akan tetapi juga berujung pada bentrok fisik antara petugas keamanan dan pedagang. Bentrokan yang terjadi sudah dua kali dilakukan dan berujung pada penahanan para ketua asosiasi pedagang. Pertama bentrokan yang terjadi pada tanggal 10 Februari 2010 ketika terjadi aksi demonstrasi di depan rumah dinas walikota dan diakhiri dengan pelemparan dan pengrusakan rumah dinas sesuai dengan STTP/9/II/2010/Intelkam. Bentrokan yang terjadi karena kekecewaan pedagang karena gagal bertemu dengan Walikota Padang. Sedangkan bentrokan kedua terjadi tanggal 31 Agustus 2011 terkait proses pelaksanaan pemagaran area Pasar Raya Padang yang akan dilakukan pembangunan.

\section{Konflik di Pasar Raya Padang sebagai Bentuk Konflik Asimetris}

Keberlanjutan dari konflik tersebut menyebabkan terbentuknya dua kelompok yang bertikai yakni pihak yang di gugat dan pihak yang menggugat. Pihak yang di gugat dalam hal ini adalah Dinas Pasar Raya sekaligus Pemerintah Kota Padang. Sementara pihak yang menggugat adalah pedagang Pasar Raya yang juga sebagai korban gempa 30 September 2009. Ada dua posisi yang berbeda dalam struktur sosial pada pihak yang berkonflik. Pemerintah Kota Padang adalah sebagai sebuah organisasi pemerintahan yang diberikan kuasa, wewenang untuk melakukan fungsi kepemerintahan. Wewenang tersebut tercipta relasi kuasa yang tidak setara dimana pemerintah memiliki posisi eksekutif. Sedangkan masyarakat berada pada posisi bawah. Konflik mengacu pada pertikaian antara pihak yang tidak memiliki (kekuatan) power dengan pihak yang lemah (power less) (Mail \& Ramsbotham, O., Woodhouse, 1999). Pemerintah bisa saja dengan kekuasaannya melakukan penekanan terhadap masyarakat, hingga masyarakat dapat dikatakan sebagai pihak yang lemah. Pemerintah pada sebagai pihak yang memiliki kekuatan ini telah menjadi pemicu terjadinya konflik di Pasar Raya Padang.

Jurnal Socius: Journal of Sociology Research and Education Vol. 8, No. 1, Th. 2021 
Kebijakan yang kelaksanakan oleh pemerintah Kota Padang pada prinsipnya adalah berdasarkan kekuasaan dan wewenang yang dimiliki tanpa melibatkan pedagang yang akan menggunakan kios darurat. Kebijakan ini tetap dilaksanakan walaupun ada protes dari pedagang. Kondisi ini diungkapkan oleh JS, bahwa:

"...Pemerintah tetap melalukan tindakan darurat dengan membangun kios darurat, kami tetap mengingatkan para pedagang untuk kembali beraktifitas dalam mengerakkan ekonomi mereka di kios darurat yang dibangun, namun ini dinilai oleh pedagang tertentu sebagai kebijakan yang salah (Wawancara pada September 2019)

Konflik antar pihak yang tidak seimbang ini membutuhkan dukungan keberpihakan dari pihak lain untuk menyeimbangi para pihak untuk mendapatkan win-win solution (Galtung, 2002). Menurut Webster, konflik merupakan ketidak kesepakatan yang tajam atau oposisi atas berbagai kepentingan, ide dll. Konflik berarti persepsi mengenai perbedaan kepentingan (perceived divergence of interest) atau suatu kepercayaan bahwa aspirasi pihak-pihak yang berkonflik tidak dapat dicapai secara simultan (Pruitt \& Rubin, 2004). Konflik juga dapat diartikan hubungan dua pihak atau lebih (individu atau kelompok) yang memiliki atau merasa memiliki, sasaran-saran yang tidak sejalan. Munculnya konflik karena kedua pihak yang berlawanan saling mengejar tujuan yang berbeda (Haryani \& Nulhakim, 2021).

Pasar Raya merupakan pusat pasar tradisional terbesar di Kota Padang. Pasar Raya merupakan aset daerah Kota Padang, yang menjadi salah satu sumber Pendapatan Asli Daerah (PAD) Kota Padang. Aset daerah ini sepenuhnya di kelola oleh pemerintah melalui Dinas Pasar. Dengan demikian bangunan-bangunan pasar ini adalah milik pemerintah dalam hal ini adalah Pemerintah Kota Padang. Dinas pasar bermitra dengan pedagang, yang mana pedagang diberikan ruang untuk melakukan aktifitas ekonomi dengan mekanisme yang telah ada di berbagai peraturan daerah. Seperti mekanisme pembelian hak guna/ hak pakai toko, kios, peruntukkan los seperti sewa los. Serta adanya mekanisme retribusi yang dipungut Dinas Pasar untuk menjadi sumber pendapatan daerah. Semua subsistem dalam pasar akan menyumbang pada subsistem lain, dengan demikikan pedagang yang begitu banyak mengorganisasikan diri kedalam organisasi-organisasi pedagang yang mereka bentuk bersama. Organisasi ini memiliki peranan penting sebagai representasi dari keseluruhan pedagang dalam memudahkan komunikasi dengan berbagai pihak terutama pemerintah Kota Padang.

Akibat gempa yang terjadi pada 2009 terdapat dua pihak yang bertikai pada konflik ini. Pertama pihak yang di gugat dan pihak yang menggugat. Pihak yang di gugat adalah Dinas Pasar Raya sekaligus Pemerintah Kota Padang. Pihak kedua adalah Pedagang Pasar Raya yang juga sebagai korban gempa 30 September 2009. Ada dua posisi yang berbeda dalam struktur sosial pada pihak yang berkonflik. Pemerintah Kota Padang adalah sebagai sebuah organisasi pemerintahan yang diberikan kuasa, wewenang untuk melakukan fungsi kepemerintahan. Dengan wewenang tersebut tercipta relasi kuasa yang tidak setara dimana pemerintah memiliki posisi eksekutif. Sedangkan masyarakat berada pada posisi bawah. Konflik asimetris mengacu pada pertikaian antara pihak yang tidak memiliki (kekuatan) power dengan pihak yang lemah (power less)(Mail et al., 1999). Pemerintah bisa saja dengan kekuasaan melakukan penekanan penekanan terhadap masyarakat sehingga masyarakat dapat dikatkan sebagai pihak yang lemah. Pemerintah kota pada sebagai pihak yang memiliki kekuatan ini telah menjadi pemicu terjadinya konflik di Pasar Raya Padang. Contoh kasus yang terjadi adalah kebijakan yang dibuat dan diksanakan oleh Pemerintah Kota Padang terkait pembangunan Kois Darurat pada hari ke 23 Pasca Gempa 30 September 2009. Pembangunan ini terjadi secara tiba tiba dengan melibatkan TNI Yon Zikon 13/kf, nilai kontrak 2,4 Milyar rupiah. Bangunan tersebut dibangun di depan Pasar Raya Inpres III yang tidak terkena dampak gempa. Pada pembangunan tersebut ada 3 persoalan, pertama pembangunan tersebut tidak di sosialisasikan dengan Pedagang, kedua jumlah kios melebihi jumlah yang dibutuhkan sehingga kios dibangun relatif kecil,

Jurnal Socius: Journal of Sociology Research and Education Vol. 8, No. 1, Th. 2021 
ketiga pembangunan kios darurat tersebut menghalangi pembeli untuk masuk pada pasar inpres II, III dan IV (Firdaus, 2014). Kebijakan yang kelaksanakan oleh pemerintah Kota Padang pada prinsipnya adalah berdasarkan kekuasaan dan wewenang yang dimiliki tanpa melibatkan pedagang yang akan menggunakan kios darurat. Kebijakan ini tetap dilaksanakan walaupun ada protes dari pedagang.

\section{Resolusi Konflik Melalui Peningkatan Kapasitas Pedagang}

Aksi protes serta penolakan yang dilakukan oleh pedagang terhadap kebijakan rehabilitasi dan rekonstruksi membuat mereka berurusan dengan hukum. Terutama setelah aksi yang dilakukan pada tanggal 10 Februari 2010, beberapa orang pedagang yang melakukan aksi, ditangkap oleh Polresta Padang. Untuk menyelamatkan anggota mereka dari proses hukum, kelompok pedagang melalui FWK mendatangi PBHI (Perhimpunan Bantuan Hukum Indonesia) Sumatera Barat untuk mendapatkan pendampingan dan perlindungan hukum.

PBHI merupakan lembaga nonprofit yang bekerja karena kepedulian sosial pada masyarakat yang terlibat pada persoalan hukum. Pada dasarnya prinsip yang dianut dalam proses pendampingannya adalah meningkatan sumberdaya manusia pihak yang mereka dampingi (Firdaus, 2016). Dalam proses pendampingan, PBHI menempatkan diri sebagai fasilitator yang mendampingi keinginan pedagang sesuai dengan kebutuhan mereka di bidang ekomomi. Proses pemdampingan dilakukan melalui pemberdayaan dengan prinsip berpusat kepada masyarakat, partisipasi, pemberdayaan dan keberlanjutan (Chambers, 1996). Pemberdayaan dilakukan dengan memberikan penguatan kepada kelompok yang berkonfllik. Penguatan yang dilakukan oleh PBHI kepada pedagang Pasar Raya Padang dapat dikelompokkan menjadi dua bentuk. Pertama, penguatan kapabilitas sumberdaya manusia, serta kedua, penguatan organisasi.

Peningkatan sumber daya manusia, yang dilakukan oleh PBHI kepada pedagang pasar raya dengan memberikan informasi terkait hak-hak pedagang sebagai korban gempa sesuai dengan UU No. 24 Tahun 2007. Informasi yang diberikan melaui penyuluhan dan sosialisasi kepada pedagang. Tujuan sosialisasi yang diberikan kepada pedagang untuk membuka wawasan mengenai kerugian yang mereka dapatkan akibat gempa. Kerugian yang didapatkan pedagang bukan saja secara materi tetapi juga akibat dari kebijakan yang dikeluarkan oleh pemerintah Kota Padang terkait revitalisasi dan rekontruksi pasar raya. Kebijakan yang dilakukan oleh pemerintah tidak ada melibatkan pedagang. Sehingga penekanan terhadap revitalisasi dan rekontruksi yang dilakukan tidak ada suara dan keinginan dari pedagang. Kondisi inilah yang disosialisasi kepada pedagang oleh PBHI.

Selain itu, pendampingan yang dilakukan oleh PBHI juga terkait dengan pengetahuan dalam perlindungan hukum dalam memperjuangkan hak-hak pedagang. Alasan pemilihan penguatan sumber daya manusia kepada pedagang agar mereka mengetahui langkah-langkah advokasi yang diambil dan tidak melanggar undang-undang. Tujuannya agar kelompok pedagang tidak berjuang dalam jalur inkonstitusional (melanggar hukum). Perjuangan pedagang takutnya diprovokasi oleh oknum-oknum yang memiliki kepentingan dan tujuan lain sehingga mengakibatkan kerusuhan dan perusakan terhadap fasilitas umum. Kondisi inilah yang melatarbelakangi perlu dilakukan penguatan sumberdaya manusia kepada pedagang. Penguatan yang dilakukan kepada pedagang juga melalui pendekatan secara sistematis kepada lembaga-lembaga lain yang dianggap bisa mewakili dan mendukung perjuangan mereka.

Menurut Dahrendorf konsiliasi merupakan salah satu bentuk pengaturan atau pengelolaan konflik. Media ini dilakukan dengan dialog secara terbuka baik lewat lembaga parlemen atau quasi-parlemen. PBHI selaku pihak pendamping dari pedagang memfasilitasi untuk lobi, dialog dengan DPRD. Dialog yang dilakukan terkait dengan aturan perundangundangan yang berlaku selain itu pedagang menginginkan proses pembangunan revitalisasi dan rekontruksi sesuai dengan keinginan mereka. Artinya perjuangan yang dilakukan bukan

Jurnal Socius: Journal of Sociology Research and Education Vol. 8, No. 1, Th. 2021 
melalui kekerasan akan tetapi menggunakan fasilitas untuk mencari resolusi yang baik. Langkah inilah yang dianjurkan oleh PBHI dalam mendampingi pedagang untuk memperjuangkan hak-hak mereka, seperti yang diungkapkan oleh Bapak FD, bahwa;

Kelemahan dari kelompok pedagang diantaranya adalah, tidak adanya pengetahuan yang cukup terkait strategi advokasi yang konstitusional atau sesuai jalur yang tidak melanggar undang undang, sehingga PBHI penting memberikan penguatan agar kelompok pedayang tidak gampang di provokasi dan diboncengi oleh kementingan lain pada kondisi konflik berkepanjangan (Wawancara pada Oktober 2019).

Upaya dialog yang dilakukan dengan DPRD membuahkan hasil, dimana DPRD memfasilitasi pertemuan antara pemerintah dengan pedagang di kantor DPRD. Pertemuan tersebut menjadi titik temu dan membuahkan hasil. Kondisi ditunjukkan dengan terjadinya penurunan intensitas konflik antara pedagang dengan pemerintah. Artinya kompromi yang dilakukan berkontribusi terhadap resolusi konflik.

Penguatan kelompok melalui organisasi formal juga merupakan salah satu mekanisme penguatan kelompok yang dilakukan oleh PBHI. Aksi-aksi yang dilakukan pedagang untuk memperjuangkan hak-hak mereka pada dasarnya dinaungi oleh kelompok pedagang. Setiap pedagang yang ada di pasar raya memiliki paguyuban yang berbeda. Proses pembentukan paguyuban yang dimiliki oleh pedagang berdasarkan lokasi jualan. Seperti kelompok pedagang pasar inpres 1, 2, 3 dan 4 bahkan kelompok pedagang batu bagonjong. Akibat perbedaan paguyuban tersebut membuat mereka tidak satu suara dalam menyikapi proses revitalisasi dan rekontruksi yang dilakukan oleh Pemerintah Kota Padang. Untuk menyamakan perbedaan, paguyuban tersebut bergabung dalam APPR (Aliansi Pedagang Pasar Raya). Melalui organisasi yang sudah tersusun secara sistimatis memudahkan PBHI dalam memberikan perhatian kepada pedagang. Dalam penguatan kelompok yang dimaksud, semua pedagang yang memiliki paguyuban masing-masing harus memberikan usulan dan pendapat terkait informasi yang dibutuhkan dalam setiap kegiatan yang dilakukan. Kondisi ini dibutuhkan agar aksi-aksi yang dilakukan oleh pedagang lebih nyata. Penguatan melaui organisasi yang diberikan oleh PBHI juga dalam bentuk pelatihan kepengurusan kelompok seperti ketua, sekretaris dan anggota terkait dengan strategi advokasi yang konstitusional dalam rangka resolusi konflik.

Penguatan yang dilakukan oleh PBHI kepada pedagang dalam bentuk peningkatan kapasitas pedagang memang membuahkan hasil. Proses revitalisasi dan rekontruksi pasar di beberapa tempat yang dilakukan oleh Pemerintah Kota Padang memang berdasarkan permintaan dari pedagang. Proses ini yang dijaga dan diawasi secara bersama PBHI, DPRD sesuai dengan kesepakatan bersama. Pedagang menyuarakan suara mereka terkait bagaimana bangunan pasar yang aman bagi pedagang. Hingga pada tahun 2015, 2016 dan 2017 pembangunan pasar kembali raya yang berdasarkan anggaran APBD dan APBN. Dengan demikian peranan PBHI dalam resolusi konflik ini bukan merupakan sebagai pihak ketiga yang tidak memiliki keberpihakan ke pihak yang bertikai, akan tetapi sebagai pihak pendamping. Seperti yang dijelaskan Afrizal bahwasanya Lembaga yang dapat dikatakan sebagai pihak Ketika dalam resolusi konflik adalah pihak yang tidak memiliki dan tidak di identifikasi memiliki keberpihakan oleh para pihak (Afrizal, 2015). Kontribusi atas perdamaian pada resolusi ini mengacu kepada transformasi kekuatan para pihak agar sama memiliki kapasitas untuk tidak ter tekan oleh pihak yang memiliki power (Martínez Guzmán \& París Albert, 2006).

\section{Simpulan}

Upaya resolusi konflik asimetris yang terjadi di Pasar Raya Padang pasca gempa dilakukan melalui proses penguatan kapasitas pedagang sebagai pihak yang berkonflik. 
Penguatan ini dilakukan melalui program pendampingan oleh PBHI untuk melindungi pedagang secara hukum. Penguatan kapasitas pedagang dilakukan dalam dua bentuk, diantaranya; pertama, penguatan sumber daya manusia dengan memberikan penyuluhan terkait hak-hak pedagang sebagai korban gempa, serta kedua, penguatan organisasi dengan memfasilitasi pedagang untuk bergabung dalam satu paguyuban yang sama sehingga memudahkan untuk memberikan informasi kepada pedagang. Melalui pendampingan ini pedagang dapat memperjuangkan hak-hak mereka secara sistematis tanpa melanggar undangundang yang berlaku.

\section{Rujukan}

Afrizal, A. (2008). Pengantar Metode Penelitian Kualitatif: Dari Penelitian Sampai Penulisan Laporan. Jakarta: PT Raja Grafindo Persada.

Afrizal, A. (2015). Third-Party Intervention in Terminating Oil Palm Plantation Conflicts in Indonesia: A Structural Analysis. Sojourn: Journal of Social Issues in Southeast Asia, 30(1), 141-172.

Ariesta, I. (2014). Peran Perempuan Dalam Resolusi Konflik Rehabilitasi dan Rekonstruksi Pasar Raya Padang. Jurnal Ilmu Sosial Mamangan, 1(2), 41-51.

Chambers, R. (1996). Participatory Rural Appraisal: Memahami Desa Secara Partisipatif. Jakarta: Kencana.

Damsar, D. (2002). Sosiologi Ekonomi (2nd ed.). Jakarta: Raja Grafindo Persada.

Firdaus, F. (2014). Protes Korban Bencana; Studi Konflik Penanggulangan Bencana di Pasar Raya Kota Padang. Jurnal Ilmu Sosial Mamangan, 1(2), 27-39.

Firdaus, F. (2016). Dari Aksi Demonstrasi ke Negosiasi; Strategi Penguatan Gerakan Pedagang Korban Bencana Pasar Raya Padang Oleh PBHI Sumbar. In I. Elfitra, M Najib Azca, Syafrudin, M.Ridha Raqwa, Vina Salviana (Ed.). Konferensi Nasional Sosiologi V, 2289-2296.

Haryani, Z. A., \& Nulhakim, S. A. (2021). Analisis penahapan konflik dan segitiga multi tingkat dalam penyelesaian konflik pembangunan Bandara Internasional di Majalengka. Jurnal Kolaborasi Resolusi Konflik, 3(1), 35-40.

Mail, H., \& Ramsbotham, O., Woodhouse, T. (1999). Contemporary Conflict Resolution. Oxford: Polity Press.

Martínez Guzmán, V., \& París Albert, S. (2006). Nuevas formas de resolución de conflictos: transformación, empoderamiento y reconocimiento. KATÁLYSIS, 9(1), 27-37.

Miles, M. . \& H. A. M. (1992). Analisis Data Kualitatif. Jakarta: Universitas Indonesia. Poloma, M. M. (1994). Sosiologi Kontemporer (1 st ed.). Jakarta: Raja Grafindo Persada. Pruitt, D. D., \& Rubin, J. Z. (2004). Teori Konflik Sosial. Yogyakarta: Pustaka Pelajar. 